\title{
CONTAINING FACTORS OF THE RUSSIAN DIGITAL TRANSFORMATION AT THE TRANSIT STAGE FROM THE FORMATION OF THE DIGITAL ECONOMY TO ITS DEVELOPMENT IN THE CONTEXT OF GLOBAL TRENDS
}

\author{
Elena Y. Zolochevskaya ${ }^{1}$, Tatyana P. Cherkasova ${ }^{2}$, Valeriya A. Arsenieva ${ }^{3}$, \\ Larisa A. Lozovova ${ }^{4}$
}

\begin{abstract}
The article reveals the concepts of innovative development and digital economy and defines their categorical correlation. The main modern trends in the development of the world economy in the context of globalization are highlighted, which implies that the digital transformation of national economies is becoming a key factor for sustainable economic growth, allowing to ensure strong competitive positions in the global space. Expert assessments of cross-country ratings in terms of the global competitiveness and innovativeness of the national economy demonstrate that the leading role in the development of the world economy belongs to the developed and rapidly developing countries at the top of these ratings. However, the leading positions some countries in the ratings are not the result of simple evolution of economic development, but a purposeful strategy of innovative development implemented through a set of public policy measures. The analysis of the state innovation policy of the USA, EU countries, Sweden and Norway, which occupy leading positions in the Digital Economy and Society Index (I-DESI) rating, made it possible to identify the main directions of economic growth that are important to consider in the Russian state policy of digitalization. As part of the study of the current state of the Russian digital transformation, the achieved success is highlighted and the constraints are identified, the elimination of which will determine the success of the development of digital technologies and their implementation in government bodies, public organizations and business structures. The successful result of Russian digitalization is the adoption of a strategic document (National Program "Digital Economy of the Russian Federation"), which defines the goals and institutional conditions for its implementation for all subjects of the national economy. Critical analysis of national programs helped to highlight some of the contained flaws, including the lack of: - economic objectives that concern system development of national industry 4.0 and the withdrawal of Russian digital technologies on global markets; - the indicative indicators of the pace of development of e-Commerce, the share of high-tech jobs in the total employment structure, growth of high-tech exports, and others; incentive mechanism for businesses to transition on the numbers; - ways to increase investment in research and development. In addition, the need for its adjustment is due to the selected seven limiting factors of Russian digitalization, which demonstrate the low efficiency of the national program in the transition from the stage of formation to the stage of development of the digital economy in Russia.
\end{abstract}

JEL Classification Number: O32, G28, DOI: 10.12955/cbup.v7.1385

Keywords: Russian economy, innovative development, digitalization, digital twins, containing factors, transaction costs, competitiveness, government policy.

\section{Introduction}

The present stage of development of the world economy is characterized by globalization processes in all spheres of public life, and, first of all, the economic sphere. This is facilitated by a number of objective tendencies caused by the rationalization of the social production in the national and world economy. Among them, the global division of labor and specialization, making all countries of the world specialize in the most competitive products and industries; the desire to reduce transaction costs in the field of international exchange; boosting the innovativeness of economic development through specialization mainly in the field of new technologies and, above all, IT technologies. World experience shows that countries, that adhere to this logic of economic development and implement the economic policies of modernization, achieve sustainable rates of economic growth and ensure their leading positions in the world system.

Expert assessments of the competitiveness and innovativeness of the Russian economy demonstrate its backwardness and dependence (especially in the financial sphere) on developed countries. The main

\footnotetext{
${ }^{1}$ South-Russian Institute of Management of Russian Presidential Academy of National Economy and Public Administration (SRIM RANEPA/Institute), Rostov-on-Don, Russian Federation, zolochevskaya @ uriu.ranepa.ru

${ }^{2}$ Department of Economics and Entrepreneurship, Faculty of Political Science at the South-Russian Institute of Management of Russian Presidential Academy of National Economy and Public Administration (SRIM RANEPA/Institute), Rostov-on-Don, Russian Federation, tcherkasova @uriu.ranepa.ru

${ }^{3}$ Department of Taxation and Accounting, Faculty of Economics at the South-Russian Institute of Management of Russian Presidential Academy of National Economy and Public Administration (SRIM RANEPA/Institute), Rostov-on-Don, Russian Federation, arsenieva@uriu.ranepa.ru

${ }^{4}$ Department of Economics and Entrepreneurship at the South-Russian Institute of Management of Russian Presidential Academy of National Economy and Public Administration (SRIM RANEPA/Institute), Rostov-onDon, Russian Federation, ectheory@uriu.ranepa.ru
} 
reason for the lag is the delay in the processes of digitalization and copying of foreign experience with the use of IT-technologies, digital platforms, payment systems and legal norms, which increases the risks of instability of the national economy. In this context, the aim of this paper is to systematize expert assessments of the Russian digital transformation and the positive results the impact of the global trend of digitalization has on it, the identification and critical analysis of constraining factors and the implementation of the national programme "Digital economy of the Russian Federation". In the future, the implementation of the goal will make it possible to specify a system of measures to correct policy of the Russian digital transformation in the transition from becoming a digital economy for its development.

The methodology is based on the concept of digital transformation and the digital economy, developed in the research by foreign (Gray \& Rumpe, 2015; Arthur, 2011) and Russian scientists (Bahanov, 2017; Zozulya, 2018; Yudina, 2017). Within the framework of this methodology, the digital economy is understood as "the process of development and implementation of innovative digital technology in economic activity, accompanied by the creation of certain legal, organizational, socio-economic and other conditions" (Gray \& Rumpe, 2015). Russian and foreign scientists and experts, on the one hand, recognize the importance and potential of the digital economy for national development (Dobrynin, Chernykh, Kupriyanovskiy \& Sinyagov, 2016; Kupriyanovskiy, Sinyagov, Lipatov, Namiot \& Vorobyev, 2016; Pfohl, Yahsi \& Kurnaz, 2015) and allocate the risks of digital transformation and peculiarities of national politics (Yudina \& Tushkanov, 2017; Yudina, 2017; Zvereva, 2017).

However, insufficient attention is paid to the study of the restraining factors of Russian digitalization in the implementation of a number of strategic policy documents, such as the "Digital economy of the Russian Federation" and the strategy for the development of the information society of the Russian Federation for 2017-2030.

As instruments of the study in the article methods used are expert evaluation, systematization of the existing approaches, assessments of innovation development and digitalization of the economy, comparison with the countries of the world leaders in digitization, identification of the positive results of the impact of the global trend of digitalization on the Russian economy, critical analysis of the limitations and constraints of the Russian digital transformation in the transition from becoming a digital economy for its development.

\section{Russia's place in the world economic system}

Modern examples of the leaders of the world economies can serve as Russia's economic competitors in the global market (Fig. 1), ranking in the top of global competitiveness (Global Competitiveness Index, GCI) Switzerland (1st place), USA (2nd place), United Kingdom (8th place) and innovation economy (Global Innovation Index, GII), Switzerland (1st place), USA (4th place), United Kingdom (5th place), etc. (The Global Competitiveness Report, 2018; Global Innovation Index 2018).

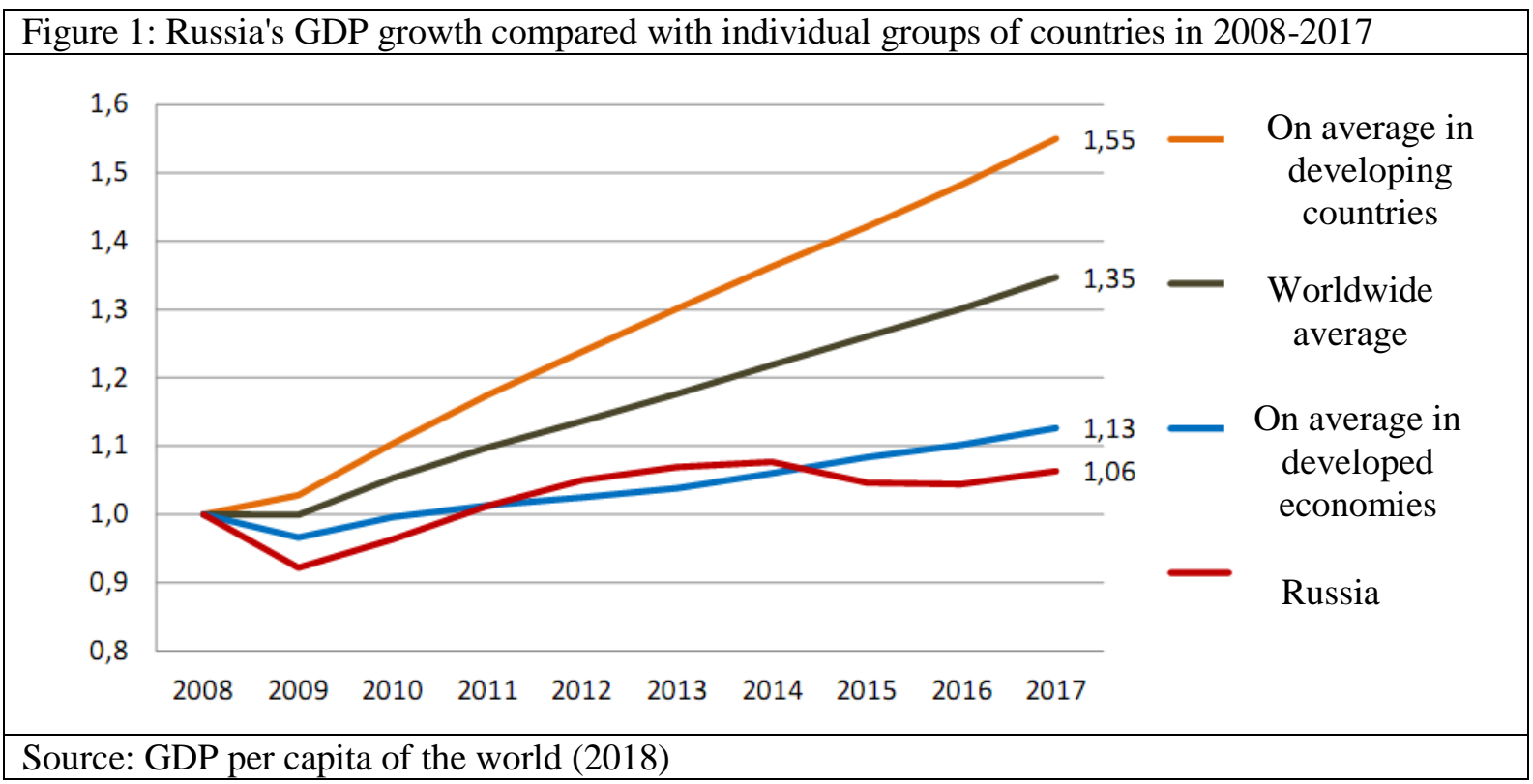


If we estimate the per capita GDP in USD, then the top 6 countries for this indicator in 2018 included: Luxembourg (110,864.07); Switzerland (80113.9); Norway (73775.53); Qatar (72961.01); Iceland (63787.96); and the United States (61053.67) (GDP per capita of the world 2018).

In these ratings Russia doesn't rank high, in $2018 \mathrm{GCI}-38^{\text {th }}$ place (from 137 countries) GII $-46^{\text {th }}$ place (from 126 countries). And post-crisis macrodynamics is below the world average (Fig. 1).

Unfortunately, expert medium term forecasts are not a comforting either, so the potential growth of Russia's GDP for 2019-2024 is estimated between $0.8-1.7 \%$ in the years 2019-2020 and no more than $3 \%$ in 2024, provided favorable global market conditions and the prevention of domestic and foreign threats to the security of the national economy. In any case, the forecast of the Ministry of Economic Development for 2019-2020 is $1.4 \%$ and $2.0 \%$, respectively, is clearly overestimated (Forecast of the socio-economic development of the Russian Federation).

The low projected rates of potential growth in Russia's GDP are due to possible risks and threats (which were widely discussed at the Gaidar Forum - 2019), among them the following should be noted:

1. Excessive role of the state in investing. Public investments are planned in the amount of 12$15 \%$, which is clearly not enough to stimulate economic growth, taking into account the growth of interest rates on loans

2. A strong correlation dependence of GDP on oil prices for the Russian economy, which increases during a decline

3. The debt load provokes an increase in the debt burden on the population, which reduces the stimulating effect on the economy in terms of the demand

4. The global economy is expected to slow down by 2021, which will affect the economic growth at the national level.

The peculiarities of the macroeconomic dynamics of Russian development and expert assessments of its competitiveness and innovativeness emphasize the need to revise the implemented state economic policy in order to modernize it in terms of increasing innovativeness (Fig. 2), in particular through digitalization.

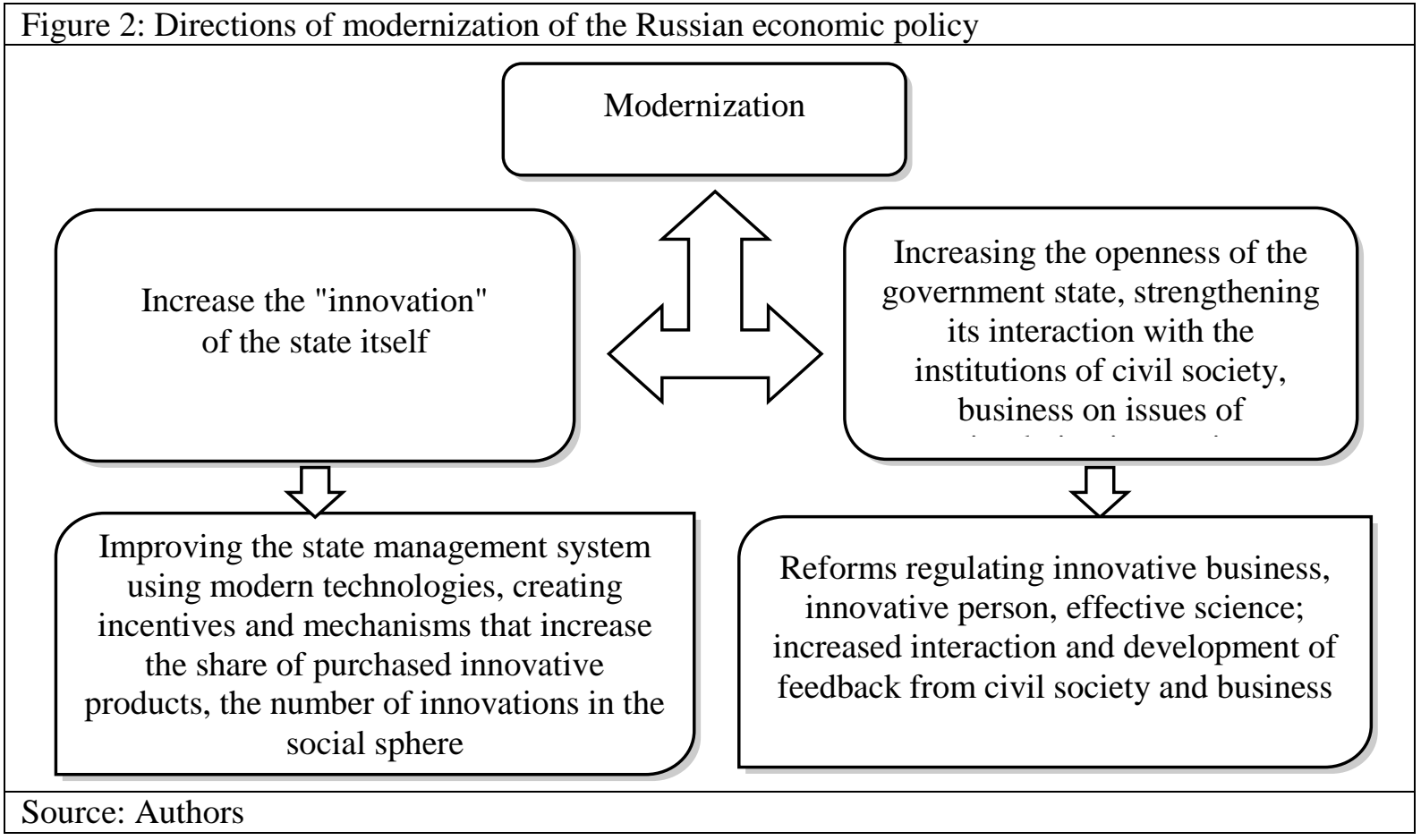

\section{Modern digital innovative trends of world development and state policy of digitalization of the} advanced powers

In recent decades, the world economy, represented by new industrial and developed countries, has accumulated a wealth of experience in creating a favorable institutional environment for introducing 
innovations in accordance with the market demand, the possibilities of satisfying it and priorities in management, production and scientific spheres. The innovation environment is treated comprehensively as a category that includes the innovation policy of the state, the provision of human resources, organizational and technological infrastructure of innovation processes, the implementation of public priorities and the entrepreneurs' willingness to innovate, etc. Currently, almost all countries are developing and implementing their own strategies for innovative development.

So, the innovation strategies of the EU countries and the USA assign a key role to creating an effective mechanism for stimulating technological and IT innovations in the business environment. The main objective of state innovation policy is to create an environment conducive to the development, implementation and mass commercialization of innovations by industrial corporations, as well as small and medium-sized companies.

Most developed countries in the world are constantly modernizing their conceptual foundations of state innovation policy. For example, Norway is characterized by the following stages of modernization: in 1999, the White Paper on Innovations was published, in 2003- the plan "From Idea to Implementation", and in 2005, the updated White Paper -"research and development commitments". The development of the designated strategic documents in Norway provided a political consensus in understanding the need to increase funding for innovations and R \& D up to $3 \%$ of GDP by 2015 (Akopova \& Panasenkova, 2012).

The Government of Sweden has developed and is gradually implementing the "Innovative Sweden" plan through interconnected government programs aimed at supporting priority industries, including information technology, communications, biotechnology, automotive, weapons production (Tretyak \& Dushevina, 2015).

In general, the modern development of the world economy demonstrates two trends of innovation and technological development: digitalization and increase in energy efficiency. If the increase in energy efficiency allows you to directly reduce production costs, then digitalization changes the quality of the production chains themselves, thanks to the achievements of scientific and technological revolution and industrial revolution.

It should be noted that the reduction of production costs by improving energy efficiency is an exhaustive factor of economic growth, which by the 21 st century is losing its degree of influence. This was demonstrated by the global energy market in the post-crisis period, when the fall in prices resulted in the curtailment of investment projects and freezing in the development of new minefields in the North Sea, the Arctic shelf and the US territory. As a result, investments in the oil and gas industry fell by $20 \%$ in the period 2014-2016, which led to an even sharper drop in profits.

Although the growth in world oil demand, combined with the strengthening of OPEC countries, provided stabilization in the global energy market in 2017-2018, the total oil production, however, fell by $12.5 \%$.

Digitization is an alternative to reducing the cost of production. The emergence of digital innovation in the global economy can be attributed to the 1960s. In fact, the digital transformation went through two stages. The first is related to the introduction of digital technologies, which boiled down to the automation of existing business processes. The second stage occurred in the mid-1990s, its distinguishing feature was the global introduction and dissemination of the Internet and mobile communications into the life of society (Kapranova, 2018). Today, the improvement of information technology infrastructure and the use of large databases have provided not only the expanded use of the Internet by millions of sellers and buyers, but also the integration of various digital services, products and systems into a single cyber-physical network. According to the McKinsey Global Institute (MGI) (Boden, Cagnin, Carabias \& Haegeman, 2010), the development of digitalization of the world economy can be comparable in scale with the industrial revolution of the $18-19$ centuries, which radically changed the world power distribution system, accelerated a number of countries industrialization and growth, and which formed the new concept of development.

Today, digitalization is a combination of the implementation of the highest IT-technologies with a high degree of automation of the production process as a whole, as well as the rapid transfer and use of a large information flow, that is transmitted from the consumer to the manufacturer. 
In recent years, the degree of digitalization is measured using such indicators such as the ICT Development Index, the Networked Readiness Index, the Digital Economy and Society Index (IDESI), the Digital Adoption Index, the IMD World Digital Competitiveness Ranking, and others. The most common is the expert assessment of the international index of the digital economy and society (IDESI), which allows you to get an assessment of how the EU is compared with non-EU economies in its progress towards digital society and economy. The indicator is calculated from 2013. The I-DESI assessment allows you to compare EU member states with 17 non-member countries, determining their effectiveness in five policy areas: connectivity, human capital (digital skills), Internet use, integration technologies and digital public services.

As shown by the calculations of the DESI Index for the entire set of EU countries, in 2017, its value compared to 2016 increased by $3 \%$, but the gap between the leaders and the countries lagging behind in the EU in digitalization is now $37 \%$ (36\% in 2014).

Looking at the evolution from 2013 to 2018, all EU member states regularly progress in the development and use of digital technologies. However, the EU as a whole failed to narrow the gap with the United States, South Korea and Japan.

The following 4 groups of countries can be distinguished according to the degree of digitalization (Fig. 3):

1. United Kingdom, Norway, Switzerland, Japan - this group of countries demonstrates the highest level of digitalization of their national economy and high growth rates

2. EU countries, Australia, South Korea - a group of countries that are characterized by a high growth rate at the initial stage of digitalization, with the attenuation of innovative activity at the present stage

3. Russia, China, India, Brazil, Turkey - countries that have the necessary potential for digital leadership

4. Countries of South America and Africa, lagging behind in terms of development.

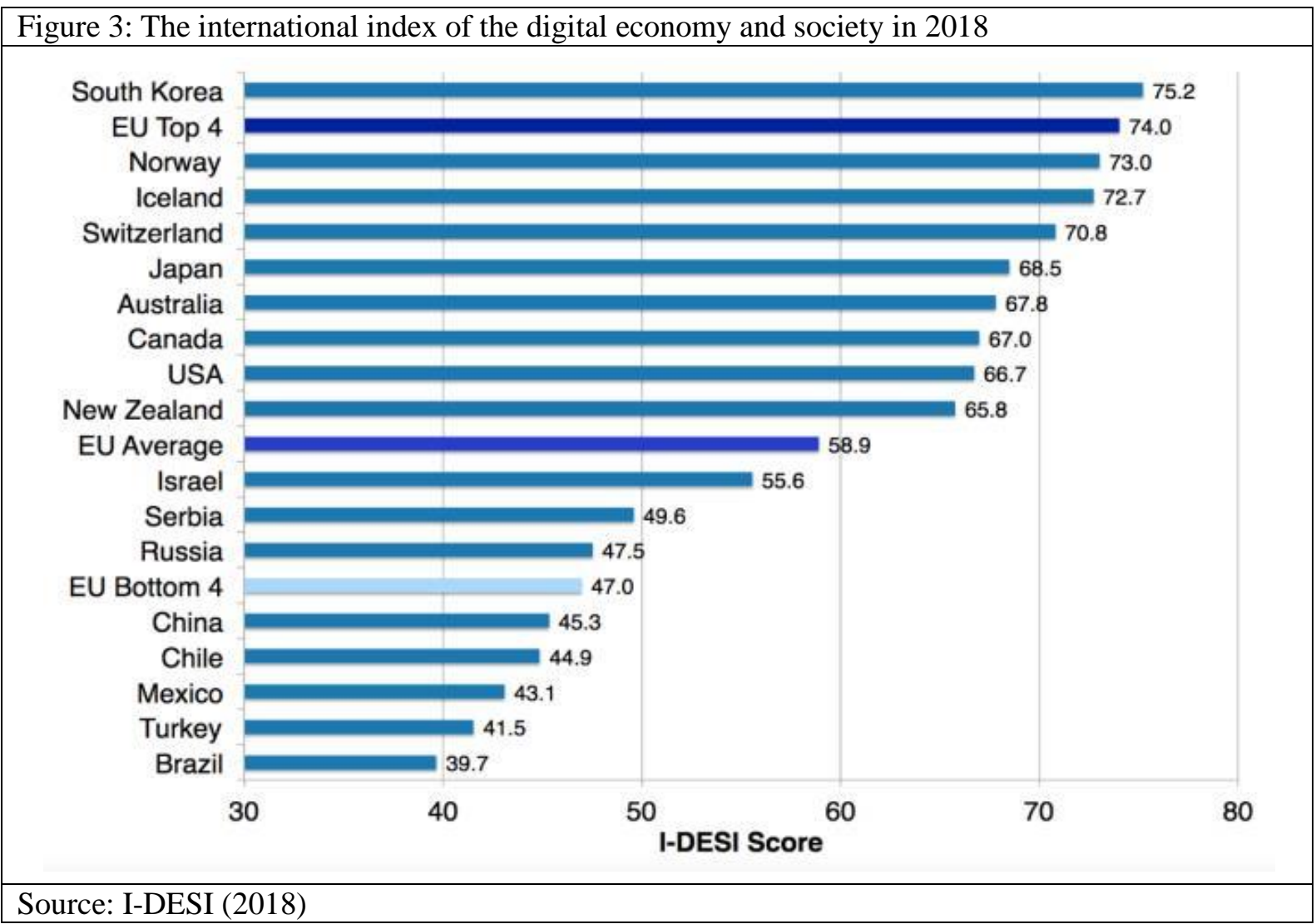

Despite the key role of digitalization in the development of the world economy, the share of digital technologies in GDP continues to not be very large. The exception is China's economy, in which the share of the figure in GDP has grown to $30 \%$ and is about $22 \%$ of the world GDP. Most likely, the 
explosive development of China's digital economy is due to the introduction of cryptocurrency, since it is there that the main mining farms are concentrated. In 2017, the position of the UK in the development of the digital economy significantly increased, its share amounted to $15 \%$ of the country's GDP. For comparison, the average share of the digital economy in the GDP of developed countries is $5-5.5 \%$ (Titov, 2018). Thus, the processes of digital transformation are not uniform in the global space.

One of the internationally proven digitalization tools of industrial production is the technology of "digital counterpart". This technology involves the creation of a computer (electronic) production model that provides effective simulation of real processes without direct intervention in the production processes themselves.

The technology of "digital twins", on the one hand, requires automation of all production processes, and on the other hand, it provides cost-free adaptation of goods to the individual needs of the client.

The experience of "digital twins" has already been tested in industrial production, for example, by Siemens in the UAE and Norway, and has shown good results in reducing both specific energy consumption costs, technogenic risks, and negative environmental impacts (Current trends of the global economy).

The development of digitalization processes is based on the development of ICT, which are supposed to create a unified management environment, a unified information space, a unified transport and logistics infrastructure, the formation of communication technologies of ultrahigh-speed information transfer, the development of "cloud infrastructure", mobile tools for external remote control, as well as the creation of new interfaces such as tactile sensors, embedded intelligent systems, brain-computer interfaces, the development of electronic-intelligent systems capable of carrying out permanent diagnostics of the state of biological and technical systems, the evolution of the Internet.

\section{Russian state policy of digital transformation: strategic documents and constraints}

A lot has already been done in the direction of digitalization of the Russian economy. The most important thing was the awareness of the need for digital transformation both at the level of the country's leadership, which was reflected in the adopted national program "Digital Economy of the Russian Federation" with the implementation period in the medium term until 2024, and at the business level, $63 \%$ of the top 100 Russian companies key sectors of the economy during the survey confirmed their readiness to digitalize business processes (Goretkina, 2018).

The essential content of Russian digitalization is defined in the Strategy for the Development of the Information Society of the Russian Federation for 2017-2030, approved by Decree of the President of the Russian Federation of 05.09.2017 No. 203, which states that "the digital economy is an economic activity in which the key factor in production is digital data, processing large volumes and using the results of their analysis in comparison with traditional forms of management can significantly improve the efficiency of various types of production, technology, equipment, storage, sales, delivery goods and services". In fact, the digital economy is the widespread use of ICT in all management and business processes, which affects the transformation of the production relations themselves.

The share of the Russian digital economy is still relatively small. The digital contribution to GDP is about 2.8\%. 2.5 million workers are involved in the digital economy, and the total infrastructure is worth 2,000 billion rubles. It has received the greatest distribution in the commercial sphere - its share is 1,238 billion rubles of the total GDP. 171 billion are accounted to marketing and advertising and 63 billion to digital content (In the forefront of the digital economy, 2018).

The success of Russian digitalization, as the experience of developed countries shows, depends primarily on the formation of a favorable institutional environment for the creation and implementation of digital innovations. The key conceptual and strategic document of the Government of the Russian Federation in this direction was the national program "Digital Economy of the Russian Federation" (approved by Decree No. 195-p of 12 February 2019), which reflects a set of priority legal acts with timelines for their adoption, as well as strategic steps to create the necessary infrastructure and training for digital transformation in different sectors and sectors of the national economy.

The objectives of the national program are as follows (National Program "Digital Economy of the Russian Federation"): 
1. An increase in the domestic costs of the economy at the expense of all sources (budget funds of different levels and private investments) and in terms of the share of GDP of at least 3 times compared to 2017

2. The creation of information technology infrastructure for high-speed transmission, processing and storage of large volumes of information accessible to all subjects of the national economy

3. The implementation of predominantly national software into the activities of all levels of government, public organizations and business structures.

Structurally the national program consists of 6 federal projects reflecting the priority areas of digital transformation in Russia, 1,634.9 billion rubles is planned to be spent on the implementation of these projects (Fig. 4).

Judging by the scale of the state project on digitalization, the internal costs of which should increase from the base $1.7 \%$ of GDP to $2.2 \%$ by the end of $2019,3.0 \%$ by the end of 2021 and $5.1 \%$ by 2024, it should become the main stimulator of economic growth in the country, directing state and private investments into priority spheres of economic development.

However, a number of obstacles make digital transformation difficult today. The main ones are the lack of competent specialists and insufficient maturity of current processes. After all, simple automation is not enough, we need reengineering of current business processes with the analysis of the inclusion of new tools into them, and this requires internal competence not only in IT-technologies, but also in the transformation of management processes.

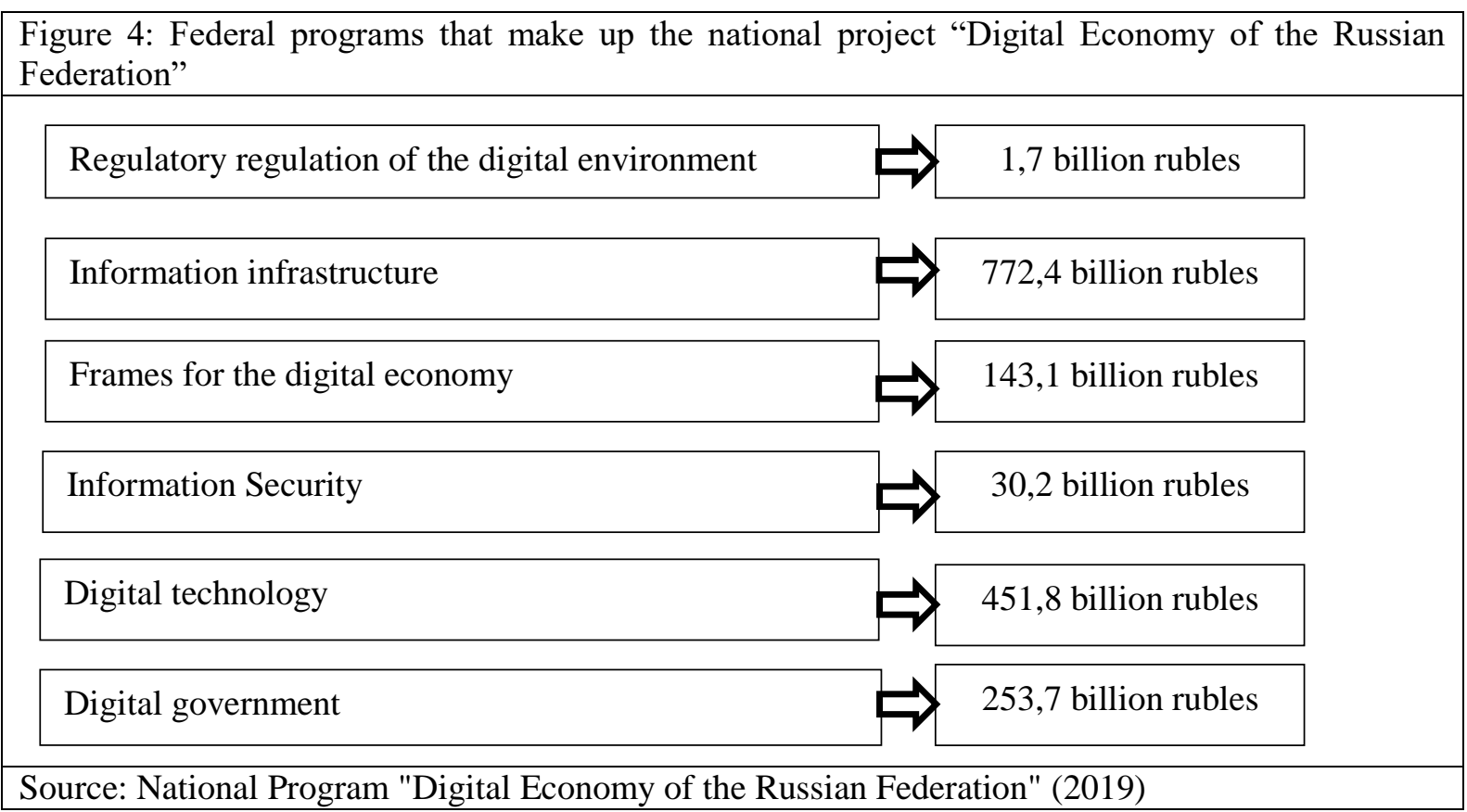

In addition, for Russian business, digitalization means a complete exit from the shadows towards transparency of business, to which small and medium-sized enterprises are clearly not ready because of weak financial stability and low competitiveness compared to large, especially foreign companies (Cherkasova \& Aksenov, 2017).

Despite the complexity of setting the goals of the national program "Digital economy of the Russian Federation" there are a number of shortcomings and unaccounted factors that continue to constrain the digital transformation and preserve the peripheral position of Russia. These include:

1) the program lacks a number of economic objectives affecting the systematic development of the national industry 4.0 and the output of Russian digital technologies to global markets;

2) the program does not include a number of indicative indicators relating to the rate of development of electronic Commerce, the share of high-tech jobs in the overall employment structure, the growth rate of high-tech exports and some other measures of the quality of digital transformation; 
3) the national program does not contain a mechanism to stimulate large corporations (mainly natural monopolies), as well as small and medium-sized businesses to move to the figure and, especially, to increase investment in research and development;

4) today, the targets of the national program are the spheres of the institutional environment (regulation, public administration and services, IT-infrastructure), which certainly plays an important role at the stage of formation and launch of digital transformation, but does not stimulate its development.

\section{Conclusion}

The analysis of digital transformation made it possible to identify leading countries and modern breakthrough technologies, allowing to optimize management and business processes, which ensures accelerated economic growth of the national economy as a whole. Modern digital technologies are changing the alignment of forces in the world arena, they have significant advantages, but neglecting the risks of digitalization can bring the national system down.

Russian digitalization is an objective reality and necessity of today. Evaluation of its state allows us to identify bottlenecks that require timely solutions, and achievements that make it possible to take advantage of the positive result of the influence of the global trend of digitalization. The main limiting factors of digital transformation at the stage of transition from formation to development of the digital economy include:

1) misunderstanding of the concept of "digital Corporation" by Russian business»;

2) unwillingness of large Russian business to switch to digital technologies and ensure transparency of all business processes;

3) the use of global electronic payment systems, and as a consequence of the vulnerability of the Russian financial system to major global players;

4) lack of computer equipment and software equipment of Russian production;

5) lack of digital legislation regulating and managing the digital economy, which creates additional institutional risks and costs;

6) lack of personnel willing to work in the digital economy and having the necessary level of eskills;

7) the presence of a large number of different programs of additional professional education "Digital economy", implemented by various universities, in the absence of common methodological approaches and understanding of the competence portrait of the graduate, demanded by the labor market of the digital economy.

As for the positive results of the impact of the global trend of digitalization, for the Russian economy they are as follows:

1) embedding in the world digital system and ensuring the acceleration of economic growth based on development of the IT sphere for example, the United States and of the transition to the "Industry 4.0 " in the example of Germany;

2) for the national economy, investments in digital assets are much more profitable than in nondigital;

3) digital technology accelerates knowledge transfer, business innovation and increases productivity;

4) digitalization of the economy contributes to the growth of living standards of citizens.

The identified constraints of the Russian digital transformation and the positive impact of the global trend of digitalization will allow the state to adjust the strategic documents of the digital economy of Russia at their subsequent stages of implementation.

\section{References}

Akopova, E.S., \& Panasenkova, T.V. (2012). Innovatsionnaya paradigma razvitiya mirovoy ekonomiki [Innovative paradigm of development of the world economy]. World economy and international relations, 8 (93), 186-191.

Arthur W.B. (2011) The second economy. McKinsey Quarterly, T. 4, 90-99.

Babanov V.N. (2017) The factors and problems of development of the digital economy in Russia [Faktory i problemy razvitiya cifrovoj ekonomiki v Rossii]// Economic and legal sciences, vol. 4-1, 255-262.

Boden, M., Cagnin, C., Carabias, V., \& Haegeman, K. (2010). Facing the future: time for the EU to meet global challenges. European Commission Joint Research Centre Institute for Prospective Technological Studies European Union, 2010 , p. 44. Retrieved from http://www.et2050.eu/docs/2010_IPTS_Facing_the_future.pdf 
Cherkasova, T.P., \& Aksenov, E.A. (2017). Sovremennyye tendentsii formirovaniya sistemy institutov publichnogo upravleniya innovatsionnym razvitiyem $v$ Rossii [Modern trends in the formation of a system of public administration institutions for innovative development in Russia]. State and Municipal Management. Proceedings of the SKAGS, 1, 55-61.

Dobrynin A.P., Chernykh K.YU., Kupriyanovskiy V.P., Kupriyanovskiy P.V., Sinyagov S.A. (2016) Digital economy different ways to effective using of technologies (BIM, PLM, CAD, IOT, Smart City, BIG DATA and others) [Tsifrovaya ekonomika - razlichnyye puti k effektivnomu primeneniyu tekhnologiy (BIM, PLM, CAD, IOT, Smart City, BIG DATA i drugiye)] // International Journal of Open Information Technologies, No.1, 4-11.

Goretkina, E. (2018). Kak tsifrovizatsiya menyayet ofis [How digitalization changes the office]. Retrieved from https://www.itweek.ru/digitalization/article/detail.php?ID=207207

Gray J., Rumpe B. (2015) Models for digitalization // Soft \& Systems Modeling, vol. 14, issue 4, 1319-1320.

I-DESI 2018: How digital is Europe compared to other major world economies? (2018). Retrieved from https://ec.europa.eu/digital-single-market/en/news/how-digital-europe-compared-other- major-world-economy

Kapranova, L.D. (2018). TSifrovaya ekonomika v Rossii: sostoyaniye i perspektivy razvitiya [Digital Economy in Russia: State and Development Prospects]. Economy. Taxes. Right, 2, 58-69.

Kupriyanovskiy V.P., Sinyagov S.A., Lipatov S.I., Namiot D.Ye., Vorob'yev A.O. (2016) Digital economy - «smart way to work» [Tsifrovaya ekonomika - «umnyy sposob rabotat'»] // International Journal of Open Information Technologies, No 2, 26-33.

Natsional'naya programma «TSifrovaya ekonomika Rossiyskoy Federatsii» [National Program "Digital Economy of the Russian Federation"]. Approved by Decree No. 195-p of 12 February 2019. Retrieved from http://government.ru/rugovclassifier/614/events/

Pfohl C.H, Yahsi B., Kurnaz T. (2015) The impact of Industry 4.0 on the supply chain. Proceedings of the Hamburg International Conference of Logistics (HICL), 31-58.

Sovremennyye tendentsii mirovoy ekonomiki [Current trends of the world economy]. Retrieved from https://www.siemens.vesti.ru

Titov, B. (2018). Rossiya: ot tsifrovizatsii k tsifrovoy ekonomike [Russia: from digitalization to a digital economy]. Moscow. Retrieved from http://stolypin.institute/institute/rossiya-ot-tsifrovizatsii-k-tsifrovoy-ekonomike/

Tretyak L.A., Dushevina E.N. (2015) Innovative trends of global economic development // Innovative economy: prospects for development and improvement, No. 5 (10), 114-119.

TSifrovaya ekonomika v Rossii [Digital economy in Russia]. Retrieved from https://ruscoins.info/faq/cifrovaya-ekonomika-vrossii/

V avangarde tsifrovoy ekonomiki (2018). Godovoy otchët gosudarstvennoy korporatsii «Rostekh» za 2017. [At the forefront of the digital economy (2018). Annual report of Rostec State Corporation for 2017]. Retrieved from http://ar2017.rostec.ru/digital-g20/

Yudina T.N. (2017) Digitalization as a trend of modern economic development of the Russian Federation: Pro Y Contra [Tsifrovizatsiya kak tendentsiya sovremennogo razvitiya ekonomiki Rossiyskoy Federatsii: Rro Y Contra] // State and municipal administration. Scientific notes SKAGS, No 3, 139-143.

Yudina T.N., Tushkanov I.M. (2017) Digital economy through the prism of the philosophy of economy and political economics [Tsifrovaya ekonomika skvoz' prizmu filosofii khozyaystva i politicheskoy ekonomii] // Philosophy of economy, No 1, 193-201.

Zozulya D.M. (2018) Digitalization of Russian economy. Industry 4.0: challenges and prospects [Tsifrovizatsiya rossiyskoy ekonomiki. Industriya 4.0: vyzovy i perspektivy] // Issues of innovative economy, Vol 8, No 1, 1-14.

Zvereva T.V. (2017) The opportunities of tax administration for minimize tax risk of the digital economy [Vozmozhnosti nalogovogo administrirovaniya po minimizatsii nalogovykh riskov tsifrovoy ekonomiki] // Innovative development of economy, No 5 (41), 86-91. 